\title{
Dimethylsulfide (DMS) and dimethylsulfoniopropionate (DMSP) in relation to phytoplankton in the Gulf of Maine
}

\author{
David W. Townsend ${ }^{1, *}$, Maureen D. Keller ${ }^{2}$ \\ 'Department of Oceanography, 5741 Libby Hall, University of Maine, Orono, Maine 04469, USA \\ ${ }^{2}$ Bigelow Laboratory for Ocean Sciences, PO Box 475, W. Boothbay Harbor, Maine 04575, USA
}

\begin{abstract}
Dimethylsulfide (DMS) and its precursor dimethylsulfoniopropionate (DMSP), in both particulate and dissolved forms, were surveyed during the early spring (March and April) and summer (July) of 1991 in coastal and offshore waters of the Gulf of Maine, USA, along with the hydrography, inorganic nutrients, phytoplankton chlorophyll, and phytoplankton taxonomic composition and abundance. Concentrations as high as $15 \mathrm{nM}$ DMS (in April and July), $208 \mathrm{nM}$ particulate DMSP (in April), and $101 \mathrm{nM}$ dissolved DMSP (in July) were recorded. Total DMSP (dissolved plus particulate) reached $293 \mathrm{nM}$ in a patch of the dinoflagellate Katodinium sp. in April. This is the first report of high DMSP concentrations in temperate waters in early spring associated with any organism other than the prymnesiophyte Phaeocystis pouchetii. There were no correlations between phytoplankton biomass, as measured by chlorophyll $a$, and DMS, and there were only slight correlations between chlorophyll a and DMSP in either dissolved or particulate form. As previously demonstrated by others, concentrations of intracellular (particulate) DMSP were related more to the presence of specific phytoplankton species rather than to overall phytoplankton biomass. The occurrence of high DMSP and DMS levels in early spring, comparable with or higher than those seen in summer maxima, at a time when bacterial activity is minimal and wind speeds are typically high may result in enhanced air-sea-fluxes of DMS.
\end{abstract}

KEY WORDS: DMS · DMSP · Phytoplankton - Gulf of Maine

\section{INTRODUCTION}

Dimethylsulfide (DMS), a volatile sulfur compound long known to be produced by marine algae (Haas 1935, Challenger \& Simpson 1948), is distributed throughout surface waters of the world ocean (Andreae 1990, Bates et al. 1992 and references therein). The flux of DMS into the atmosphere and its subsequent photo-oxidation are important processes in the global sulfur cycle and have been implicated in acid precipitation and the formation of cloud condensation nuclei. DMS is the most important biogenic sulfur compound in the atmosphere (Bates et al. 1987. Charleson et al. 1987). The precursor of DMS is dimethylsulfoniopropionate (DMSP), which, in the case of planktonic algae, is produced especially by

•E-mail: davidt@maine.maine.edu members of the classes Dinophyceae and Prymnesiophyceae (Andreae et al. 1983, Keller et al. 1989).

Studies of the distributions of DMS and DMSP in the marine environment have shown that there is significant spatial and temporal variability of both compounds in surface waters of the oceans, where phytoplankton are generally highest (Holligan et al. 1987, Turner et al. 1988, Malin et al. 1993, Matrai \& Keller 1993). However, since the biosynthesis of DMSP by phytoplankton is species-specific, there are usually only weak correlations between phytoplankton biomass, as indicated by chlorophyll a concentrations, and DMS or DMSP concentrations in sea water (Barnard et al. 1982, Bates \& Cline 1985). In addition, the conversion of DMSP to DMS is accomplished by a number of biologically-mediated processes, such as phytoplankton cell lysis, bacterial degradation, or grazing by zooplankton (Dacey \& Wakeham 1986, Nguyen et al. 
1988, Belviso et al. 1990, Kiene \& Bates 1990, Matrai \& Keller 1993). Thus, to construct budgets for DMSP production and DMS release in the oceans, it is necessary to know not only the concentrations of DMS and DMSP in seawater, but also plankton community structure and trophodynamics.

Concentrations of DMS and DMSP are generally higher in coastal and shelf waters than in the open oceans, and highest concentrations have been recorded during blooms of specific phytoplankton taxa, notably the prymnesiophytes Phaeocystis pouchetii and Emiliania huxleyi, and the dinoflagellate Gyrodinium aureolum (Barnard et al. 1984, Turner et al. 1988, Malin et al. 1993, Matrai \& Keller 1993). With the exception of $P$. pouchetii, these taxa and associated elevated levels of DMSP occur during the warmer months.

The Gulf of Maine, a biologically productive continental sheif sea on the east coast of Norih America, seasonally experiences a variety of phytoplankton blooms. Many of the bloom species are known producers of substantial quantities of DMSP and DMS. We report here the results of 3 research cruises in the Gulf of Maine in the spring and summer of 1991, during which we surveyed the distributions of DMS and DMSP in relation to the hydrography, nutrients, and the biomass and taxonomic composition of the phytoplankton. Our goal was to obtain data from different periods of the year when it was anticipated that DMSP and DMS would be low (winter and spring) and high (summer and fall) to use in the development of an annual budget and eventual model of DMS emissions from the Gulf of Maine.

\section{MATERIALS AND METHODS}

Three oceanographic surveys were conducted in the spring and summer of 1991: 15-17 March, aboard the RV 'ARGO-Maine', when we surveyed the inshore waters of the western Gulf of Maine, and 21-30 April and 5-14 July, aboard the RV 'Cape Hatteras', when we surveyed most of the offshore waters of the Gulf proper. On each cruise, we surveyed the hydrography using a CTD and rosette water sampler equipped with Niskin bottles. Vertical profiles of phytoplankton chlorophyll a were determined fluorometrically (Parsons et al. 1984) on bottle samples by filtering $100 \mathrm{ml}$ through a $25 \mathrm{~mm}$ Whatman GF/F filter and extracting the pigments for at least $24 \mathrm{~h}$ in $90 \%$ acetone at $-20^{\circ} \mathrm{C}$ in the dark. Inorganic nutrient concentrations were analyzed using standard autoanalyzer techniques

Subsamples for quantitative phytoplankton analyses were preserved immediately with $50 \%$ glutaraldehyde to a final concentration of $0.5 \%$, filtered sequentially onto 8,3 and $0.2 \mu \mathrm{m}$ Nuclepore filters and frozen until enumeration. Samples were examined using a Zeiss Axiomat epifluorescence microscope. In addition, vertical net tows $(25 \mu \mathrm{m}$ mesh) were made and the samples fixed with Lugol's iodine solution to provide a qualitative estimate of larger phytoplankton. These samples were examined using settling chambers and a Zeiss inverted microscope. Chlorophyll-containing cells in each of the filtered size fractions were counted using epifluorescence microscopy, and cells identified, when possible, into major taxa or pigment groups, e.g. diatoms, dinoflagellates, coccolithophores, cryptomonads, and phytoflagellates; cells comprising greater than $1 \%$ of the population were identified to genera or species, if possible. A minimum of 100 cells were counted in each sample.

Samples for DMS and DMSP were collected into $250 \mathrm{ml}$ glass, gas-tight syringes with luer-lock fittings, idking care to minimize air bubbles. These samples were held inside the ship's laboratory in cool, dim conditions until analysis, generally within an hour. Subsamples for DMS analysis were sparged with nitrogen gas for periods of 5 to $30 \mathrm{~min}$, depending on sample size, cryotrapped and subsequently injected into a gas chromatograph with FPD detector (Varian 3300, Chromosil 330 column). Subsamples for DMSP were placed in serum vials, $1 \mathrm{ml}$ of $5 \mathrm{M} \mathrm{KOH}$ added, and the vials promptly sealed. Additional subsamples were gently filtered through a GF/F filter, and the filtrate was placed in serum vials and treated as above. These treatments represent respectively the total [DMSP(T)] and dissolved DMSP [DMSP(D)] present in each sample. These samples were stored in the dark and analyzed at a later date for DMS as above. Samples can be stored in this manner for several months without loss of DMS (Keller unpubl.) The addition of base is known to specifically and completely breakdown DMSP to DMS (Challenger \& Simpson 1948). Particulate DMSP [DMSP(P)] was calculated by difference between DMSP(T) and DMSP(D). Standards were prepared from known quantities of DMSP (Research Plus, Inc.) and analyzed similarly. The detection limit of the system is approximately $0.1 \mathrm{nM}$. The precision of the method is approximately $5 \%$. No DMS analyses were done on the March cruise, due to equipment failure.

\section{RESULTS AND DISCUSSION}

Seasonal distributions of chlorophyll a, DMS and DMSP for the 3 cruises are presented as areal contour plots in Figs. 1 to 3. During the first survey cruise in March, we observed 2 patches of high phytoplankton biomass in separate areas of the western Gulf of Maine 

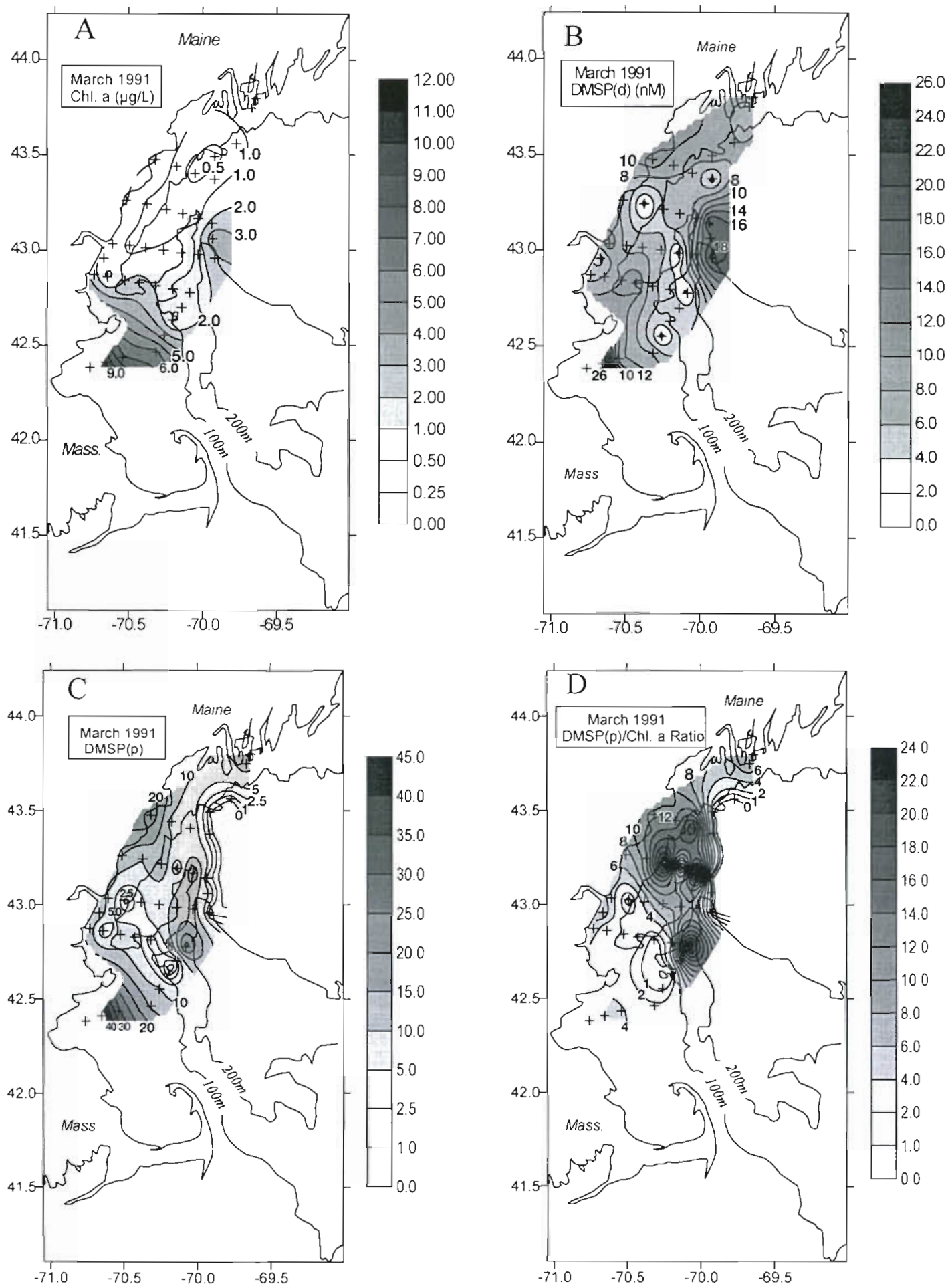

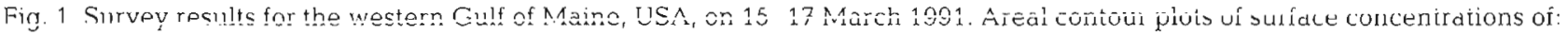
(A) chlorophyll a $\left(\mathrm{g} \mathrm{g}^{-1}\right)$; (B) dissolved DMSP (nM); (C) particulate DMSP (nM); (D) chlorophyll-specific DMSP(P), i.e. the ratio of particulate DMSP to chlorophyll a. Contours were made using Surfer for Windows, Ver. 3.01 (Golden Software). The $100 \mathrm{~m}$ and $200 \mathrm{~m}$ isobaths are labeled; station locations are indicated by crosses 
(Fig. 1A). Surface chlorophyll a concentrations exceeded $10 \mathrm{\mu g} \mathrm{l}^{-1}$ at the southwestern-most stations in Massachusetts Bay, and exceeded $3.5 \mu \mathrm{g} \mathrm{l}^{-t}$ in a second patch toward the east and further offshore. Chlorophyll concentrations were also slightly elevated
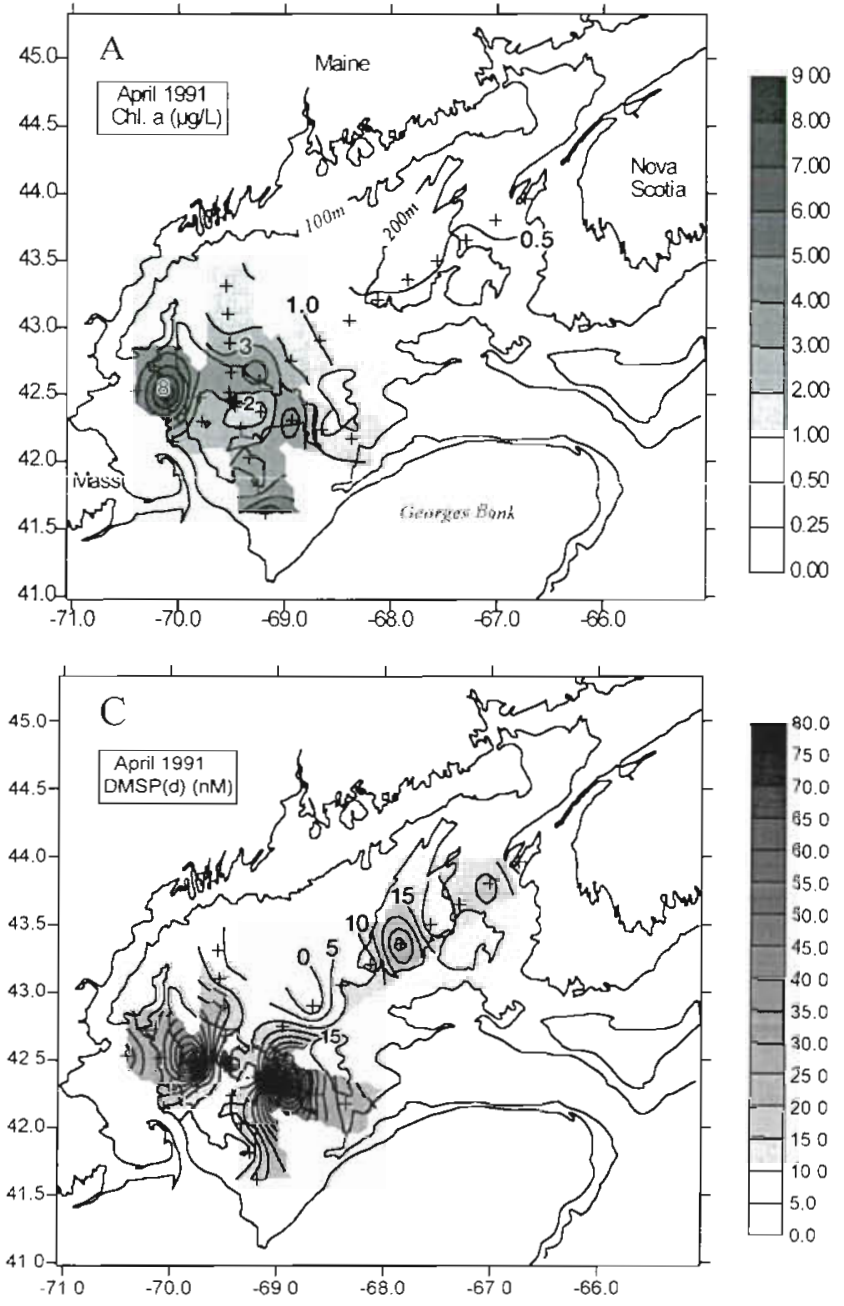

Fig. 2. Survey results for the Gulf of Maine, USA, on 21-30 April 1991 Areal contour plots of surface concentrations of: (A) chlorophyll a ( $\left.\mathrm{gg} \mathrm{l}^{-1}\right)$ : (B) DMS (nM); (C) dissolved DMSP (nM) (note: maximum values of DMSP(D) exceeded $175 \mathrm{nM}$ at Stn 23, but are not contoured here $]_{i}$ (D) particulate DMSP $(\mathrm{nM})_{i}(\mathrm{E})$ the ratio of particulate DMSP to chlorophyll a. The $100 \mathrm{~m}$ and $200 \mathrm{~m}$ isobaths are labeled; station locations are indicated by crosses. The locations of Stns 10 and 23 are indicated in Panel D along the immediate shoreline. We observed relatively high surface nutrient concentrations, which were still near maximal wintertime values $\left(>10 \mu \mathrm{M} \mathrm{NO} \mathrm{NO}_{3}-\mathrm{N}_{\text {i }}\right.$ Townsend 1991), indicating that these 2 bloom patches were just getting underway. Silicate was significantly
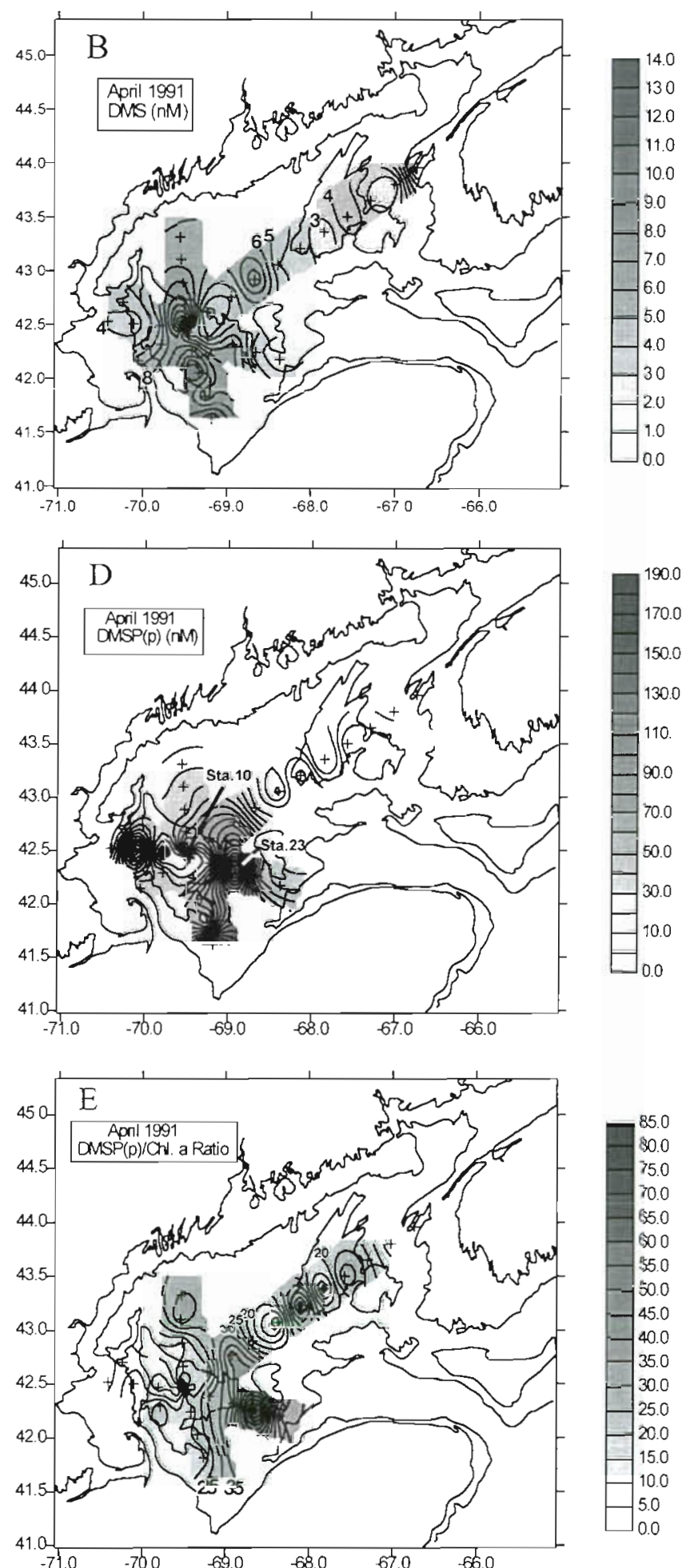


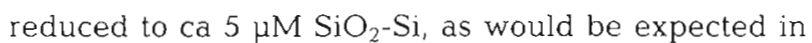
a diatom-dominated community. Concentrations of DMSP(D) in March ranged from ca $1 \mathrm{nM}$ in the lowchlorophyll a waters to greater than $29 \mathrm{nM}$ in Massachusetts Bay, where chlorophyll a was highest;
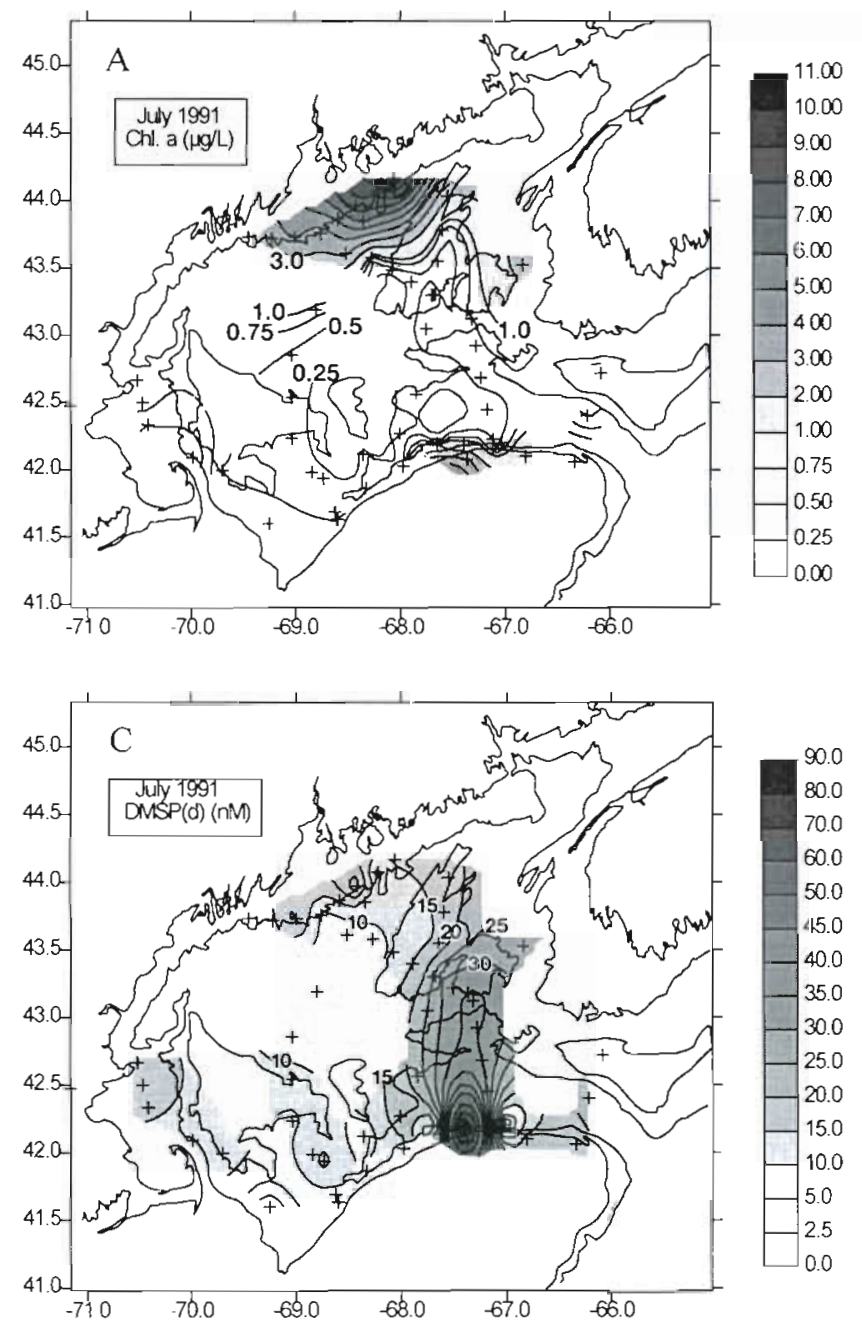

Fig. 3. Survey results for the Gulf of Maine, USA, on 5-14 July 1991. Areal contour plots of surface concentrations of: (A) chlorophyll a ( $\left.\mathrm{g} \mathrm{l}^{-1}\right)$; (B) DMS (nM); (C) dissolved DMSP $(n M)_{i}(D)$ particulate DMSP (nM); (E) the ratio of particulate DMSP to chlorophyll a. Station locations are indicated by crosses. The locations of Stns 5, 13, 47,62 and 66 are indicated in Panel D

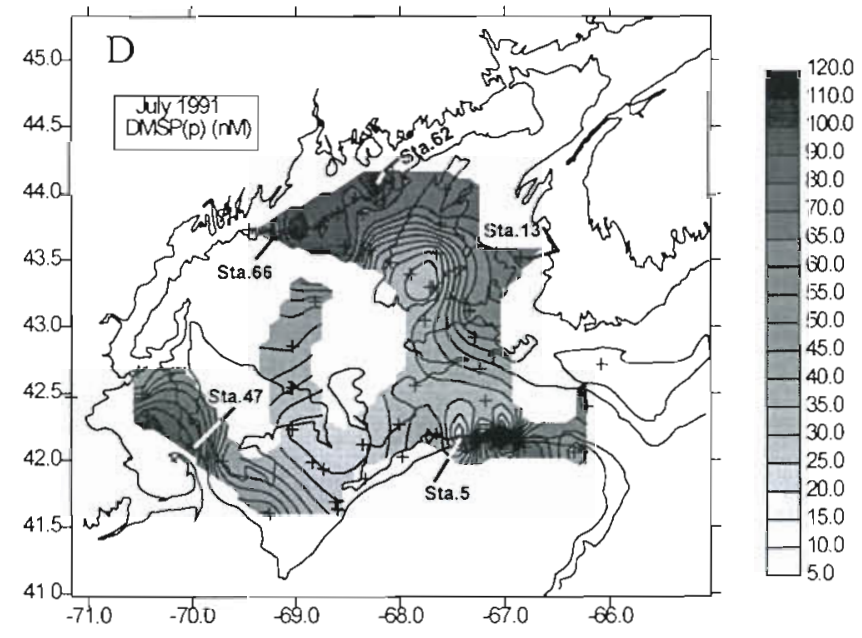

DMSP(D) were also relatively high (ca $19 \mathrm{nM}$ ) in the offshore bloom patch in the eastern-most portion of the survey area (Fig. 1B). The concentrations of intracellular DMSP, or DMSP(P), were also highest in Massachusetts Bay where they reached $50 \mathrm{nM}$, while concentra-
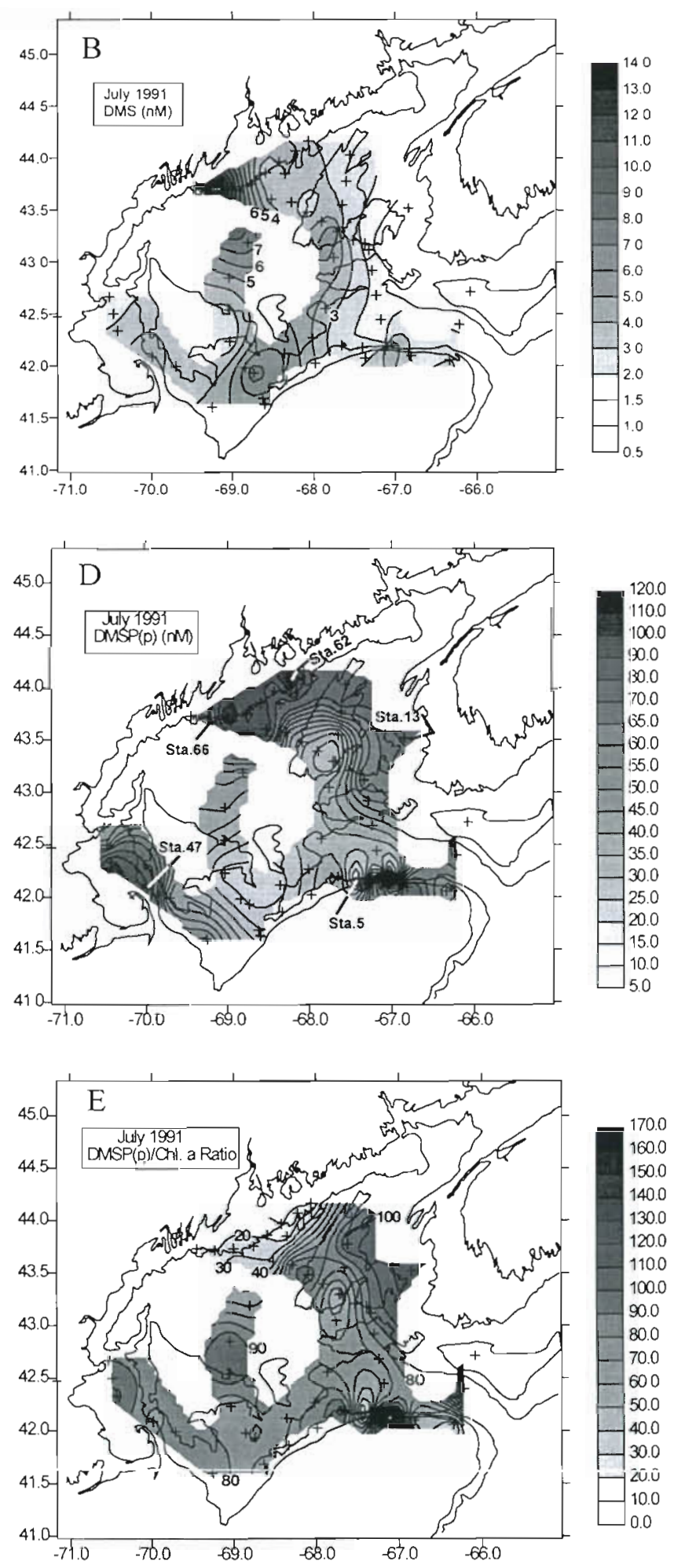

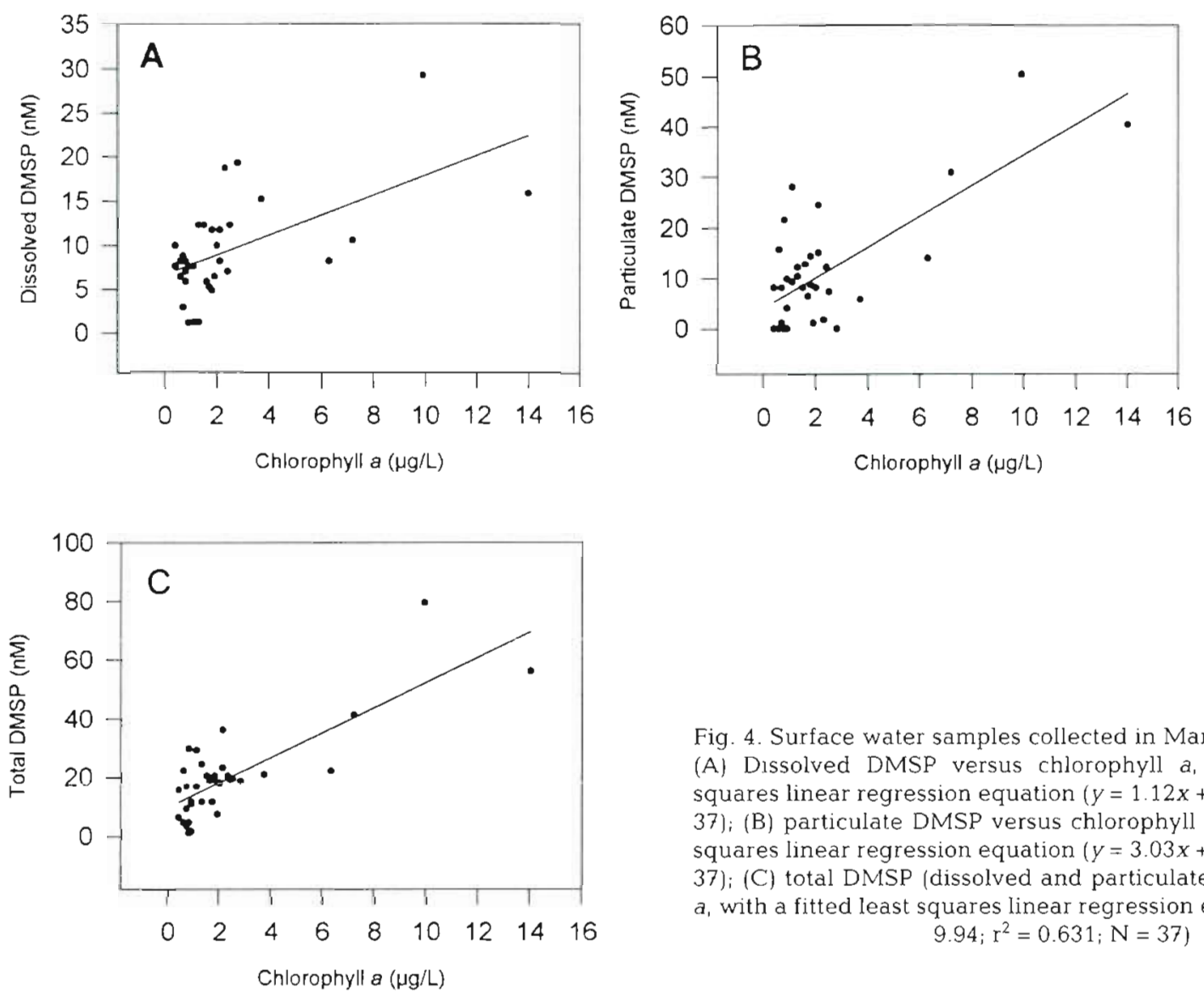

Fig. 4. Surface water samples collected in March 1991 (see Fig. 1) (A) Dissolved DMSP versus chlorophyll $a_{1}$ with a fitted least squares linear regression equation $\left(y=1.12 x+6.64 ; r^{2}=0.335 ; N=\right.$ 37); (B) particulate DMSP versus chlorophyll $a_{1}$ with a fitted least squares linear regression equation $\left(y=3.03 x+4.14 ; r^{2}=0.539 ; \mathrm{N}=\right.$ 37); (C) total DMSP (dissolved and particulate) versus chlorophyll $a_{1}$ with a fitted least squares linear regression equation $(y=4.26 x+$ $9.94 ; \mathrm{r}^{2}=0.631 ; \mathrm{N}=37$ )

tions offshore toward the east were only moderately elevated (ca $28 \mathrm{nM}$ ) as were those in the coastal waters on the Maine coast (ca 14 nM) (Fig. 1C). DMSP concentrations were only weakly correlated with chlorophyll a concentrations (Fig. 4), but those correlations were positively influenced by a relatively few data points (4) with elevated chlorophyll $a$ and DMSP concentrations. Thus, the levels of DMSP could not be directly correlated to phytoplankton biomass, as measured by chlorophyll $a_{\text {; }}$ in fact, there was little coherence among levels of chlorophyll $a_{1}$ intracellular DMSP(P), or chlorophyll-specific DMSP(P) as seen in the areal contour plots in Fig. 1. The characterization of the phytoplankton in March was qualitative. Only dominant species were identified from prepared slides and net tows. The population in Massachusetts Bay was largely a mixed diatom community with Phaeocystis sp. in colonial form being a co-dominant. The dominant diatoms included species of Thalassiosira and Chaetoceros, especially $C$. socialis. The bloom area offshore to the east was comprised mainly of diatoms of the genera Nitzchia, Rhizosolenia and Thalassiosira. No Phaeocystis colonies were observed in the east, but there was a variety of small phytoflagellates, some of which may have been single cells of Phaeocystis.
The Gulf-wide survey in April (Fig. 2) was designed with the goal of sampling the Gulf of Maine spring diatom bloom. We began our survey with a transect that ran from the eastern Gulf, which is slower to vertically stratify in spring, to the western Gulf, where stratification and a diatom bloom typically occur earlier (Townsend 1991, Townsend et al. 1992). The highest chlorophyll a concentrations were in the western Gulf (Fig. 2A), but they were not correlated with DMS (Figs. 2B \& 5) and were only weakly correlated with DMSP(D) or DMSP(P) (Figs. 2C, D, E \& 5). In fact, there was little or no coherence among chlorophyll $a$, DMS and DMSP as seen in the areal contour plots in Fig. 2A-E. DMS concentrations ranged from ca 2 nM to $>15 \mathrm{nM}$ in the central western Gulf (Fig. 2B), where concentrations of DMSP(D) reached $175 \mathrm{nM}$, and of DMSP(P) were greater than $200 \mathrm{nM}$.

The phytoplankton data for April are quantitative as well as qualitative, but it remains problematic to ascribe DMS or DMSP to any one group of species since the population at any one station was taxonomically diverse. However, the differences in the phytoplankton taxonomic composition between stations can explain in part the fluctuations in DMSP over a small area. For example, Stns 10 and 23, both in the central 

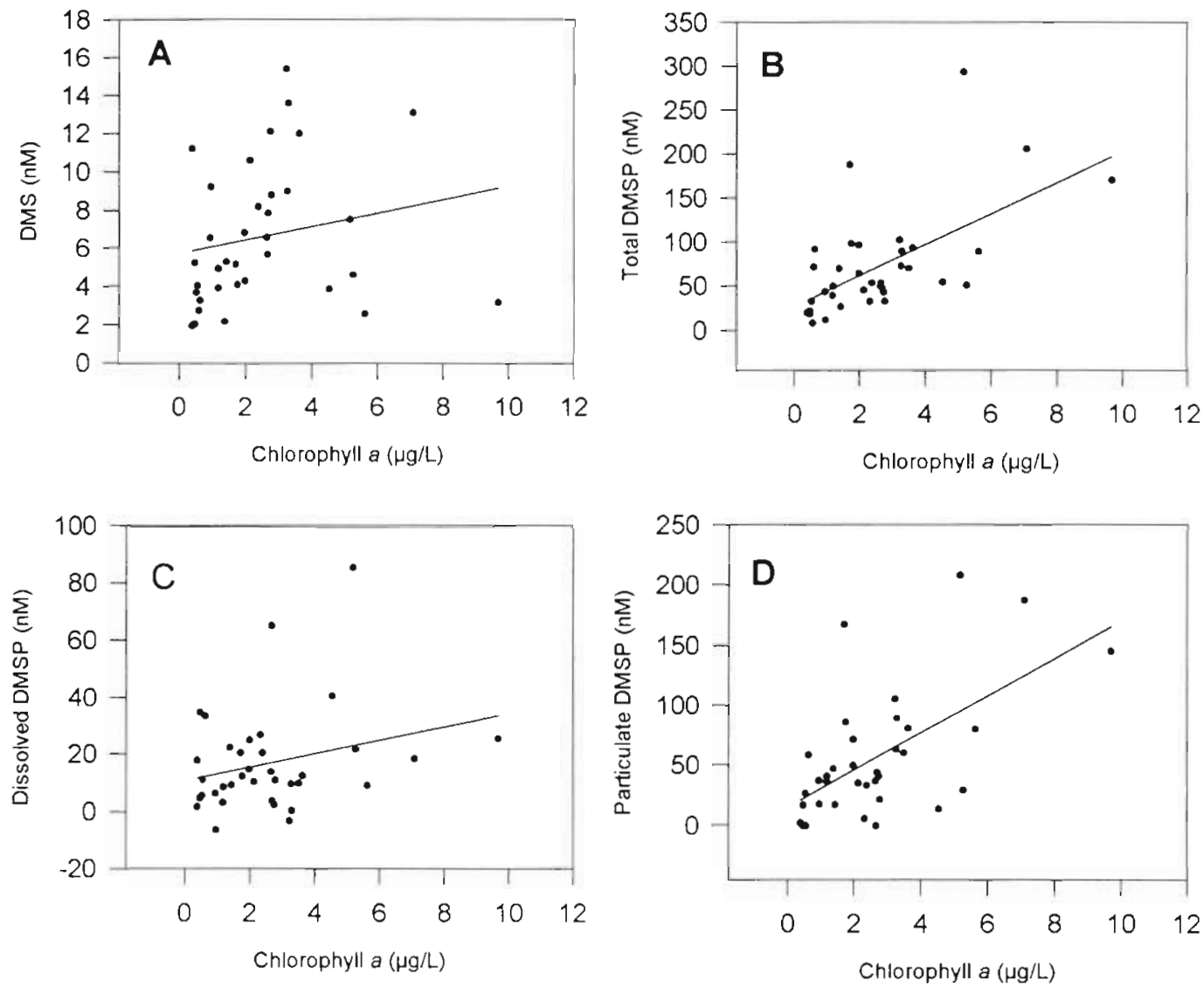

Fig. 5. Surface water samples collected in April 1991 (see Fig. 2). (A) DMS versus chlorophyll a, with a fitted least squares linear regression equation $\left(y=0.35 x+5.7 ; \mathrm{r}^{2}=0.041 ; \mathrm{N}=35\right) ;(B)$ total DMSP (dissolved and particulate) versus chlorophyll $a$, with a fitted least squares linear regression equation $\left(y=17.512 x+27.3 ; \mathrm{r}^{2}=0.363 ; \mathrm{N}=37\right)$; (C) dissolved DMSP versus chlorophyll a, with a fitted least squares linear regression equation $\left(y=2.36 x+10.87 ; \mathrm{r}^{2}=0.072 ; \mathrm{N}=35\right)$; (D) particulate DMSP versus chlorophyll $a$, with a fitted least squares linear regression equation $\left(y=15.52 x+15.03 ; \mathrm{r}^{2}=0.365 ; \mathrm{N}=35\right)$

western Gulf (see Fig. 2D for locations), had significant phytoplankton biomass (surface chlorophyll $a>5 \mu \mathrm{g} \mathrm{l}^{-1}$ ). The composition of that biomass was quite different, however (Fig. 6). Stn 10 was dominated by the diatom Chaetoceros sp. $\left(3.5 \times 10^{5}\right.$ cells $~^{-1}$ at $\left.4 \mathrm{~m}\right)$, while Stn 23 was dominated by the dinoflagellate Katodinium sp. $\left(1.2 \times 10^{6}\right.$ cells $1^{-1}$ at $\left.2 \mathrm{~m}\right)$. This alga is known to bloom densely in Chesapeake Bay (USA) during the winter months (Sellner et al. 1991), but this is the first record of a bloom of this species in the Gulf of Maine, and the first account of high levels of DMSP associated with it. Diatom blooms are commonly observed in the Gulf of Maine at this time of year and they are known to be variable in their timing (Townsend \& Spinrad 1986, Townsend et al. 1992, 1994). As indicated by the low surface nutrient concentrations that we observed along the transect of stations extending from Nova Scotia to Cape Cod
$\operatorname{Stn} 10$
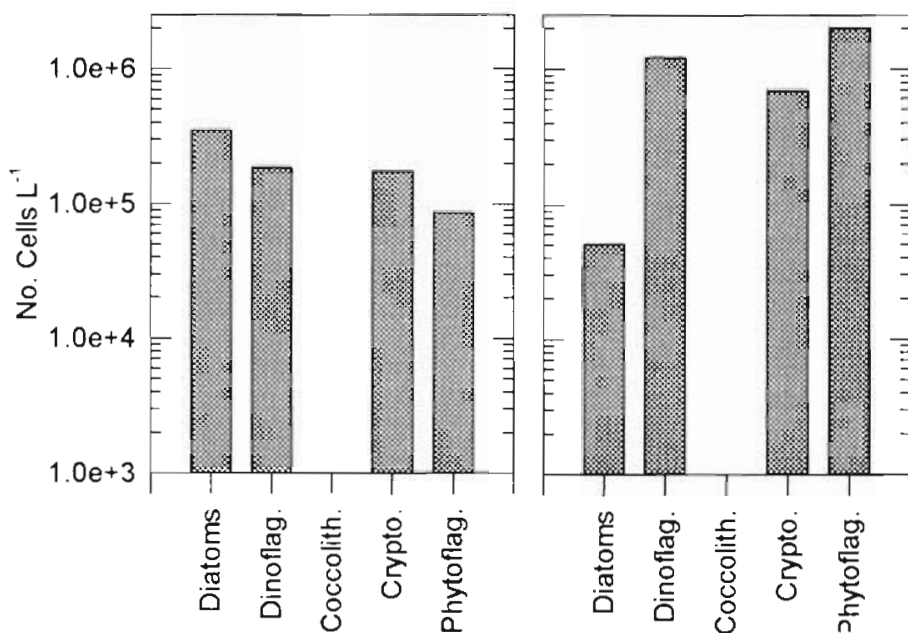

Fig. 6. Cell densities for major taxonomic groups of phytoplankton (diatoms, dinoflagellates, coccolithophores and phytoflagellates) for surface waters at Stns 10 and 23, April 1991 (Note the log scale) 

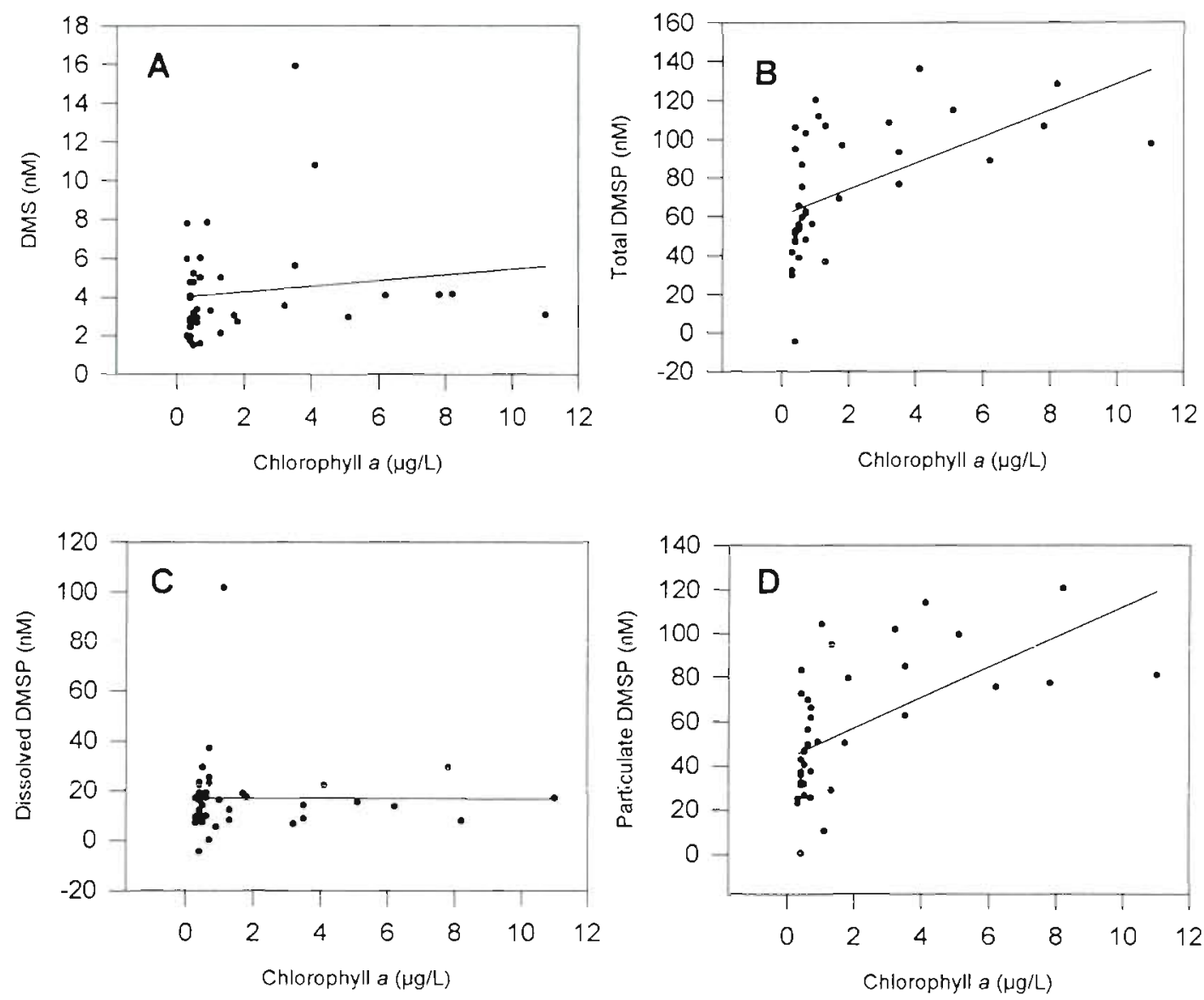

Fig. 7. Surface water samples collected in July 1991 (see Fig. 2). (A) DMS versus chlorophyll a, with a fitted least squares linear regression equation $\left(y=0.145 x+3.9 ; r^{2}=0.019 ; N=51\right) ;(B)$ total DMSP (dissolved and particulate) versus chlorophyll $a_{\text {, }}$ with a fitted least squares linear regression equation $\left(y=6.84 x+60.3 ; r^{2}=0.297 ; N=39\right)_{i}(C)$ dissolved DMSP versus chlorophyll $a$, with a fitted least squares linear regression equation $\left(y=-0.02 x+16.9 ; \mathrm{r}^{2}=0.001 ; \mathrm{N}=39\right)$; (D) particulate DMSP versus chlorophyll $a_{\text {, }}$ with a fitted least squares linear regression equation $\left(y=6.86 x+43.46 ; r^{2}=0.341 ; N=40\right)$

(1.0 to $2.7 \mu \mathrm{M} \mathrm{NO} \mathrm{NO}_{3}-\mathrm{N}$ and 0.2 to $2.7 \mu \mathrm{M} \mathrm{SiO}{ }_{2}-\mathrm{Si}$ ), it appeared that we arrived after the main diatom bloom that spring. Phaeocystis sp. was not observed in these samples. We attempted to correlate DMS and DMSP concentrations with individual species by using cell numbers of individual species to subdivide the data $\left(>10^{4}\right.$ cells $l^{-1}$ for large cell types and $>10^{5}$ cells $l^{-1}$ for smaller cell types). Most correlations were poor $\left(r^{2}=\right.$ 0.2 to 0.3 ). We believe this is due to the diversity represented in typical populations and our inability to appropriately weigh the co-dominants. There were a few stations in April where the dinoflagellate Katodinium sp. completely dominated, with cell numbers $>10^{6}$ cells $~^{-1}$ At these stations $(n=5)$, the mean $\operatorname{DMSP}(\mathrm{T})$ concentration was $210 \mathrm{nM}$ (range $=104$ to $314 \mathrm{nM}$ ) and the mean DMS concentration was $11.4 \mathrm{nM}$ (range $=5.2$ to $16.2 \mathrm{nM}$ ). On a per cell basis, the DMSP content was ca 12 to 42 pg cell ${ }^{-1}$, which is consistent with concentrations previously measured in laboratory cultures of similar sized dinoflagellates 16 to $43 \mathrm{pg} \mathrm{cell}{ }^{-1}$; Keller et al. 1989). The presence of the dinoflagellate population, superimposed upon or replacing the typical diatom flora, is noteworthy, and makes generalizations about temporal or spatial production of DMSP and DMS more difficult.

In July, we observed relatively low summertime phytoplankton biomass throughout the central Gulf, associated with nutrient depletion, and higher chlorophyll a concentrations around the periphery (Fig. 3A). For example, chlorophyll a concentrations exceeded $11 \mu \mathrm{g} \mathrm{l}^{-1}$ in an area in the northern Gulf, which includes part of the eastern Maine coastal current of nutrient-rich, tidally-mixed waters (Townsend et al. 1987). Concentrations were $5 \mu \mathrm{g} \mathrm{l}^{-1}$ or more in the surface waters off the Nova Scotian shelf, on the northern edge of Georges Bank, and just off Cape Cod. There was no correlation between DMS and chlorophyll a concentrations (Figs. 3B \& 7), and only very weak cor- 
relations between DMSP(D) or DMSP(P) and chlorophyll a (Figs. 3 \& 7). The surface water concentrations of DMS in July were as high as $16 \mathrm{nM}$ (off the Maine coast; Fig. 3B), with most values between 0 and 8 nM. DMSP(D) concentrations reached $>100 \mathrm{nM}$ over the deep basin off the northern edge of Georges Bank, and DMSP(P) reached $169 \mathrm{nM}$ at Stn 13 off the coast of Nova Scotia (Fig 3D). There were several stations where DMSP values exceeded $100 \mathrm{nM}$.

The phytoplankton populations at various stations were diverse and not clearly dominated by any one species. The community structure in July for 5 stations where either DMS, DMSP(P) or chlorophyll a levels were high is given in Fig. 8. The community at Stn 13 (with surface chlorophyll $a=2.4 \mu \mathrm{g}$ $\left.1^{-1}\right)$ was composed of the prymnesiophytes Emiliania huxleyi and Chrysochromulina sp., cryptomonads, and dinoflagellates of the genera Katodinium and Gymnodinium. All of these algae, with the possible exception of the cryptomonads, are known to produce DMSP (Keller et al. 1989). Similar patterns of relatively low chlorophyll but relatively high DMSP(P) can be seen for Stns 5 and 47 (Fig. 3), which also had Emiliania and Katodinium populations and high densities of uncharacterized, small phytoflagellates. Stn 62, which had much higher surface water biomass $(7.7 \mu \mathrm{g}$ chlorophyll a $\mathrm{l}^{-1}$ ) and substantially lower, but not insignificant, DMSP(P) levels ( $73 \mathrm{nM})$, had a mixed diatom population dominated by Chaetoceros sp. and Leptocylindrus minimus. Lesser dominants were the dinoflagellates Alexandrium, Scrippsiella and Dinophysis. Stn 62 is in the eastern Maine coastal current system and typically exhibits high numbers of diatoms throughout the warmer months. This is in response to injections of deep-water nutrients to the surface in the tidally wellmixed waters of the eastern Gulf of Maine (Townsend et al. 1987). Both Alexandrium and Scrippsiella produce large quantities of DMSP (Keller et al. 1989); to our knowledge, Dinophysis has not been evaluated, and the diatoms are considered to be minor producers Because of the mixed population, it is impossible to separate out the source(s) of the DMSP, as it is not strictly a function of the presence of any one species. Exceptional biomass, such as that found in the eastern Maine coastal current, can result in sizeable pools of DMSP. For example, at Stn 66, further to the west and downstream from Stn 62 along the coastal current
$\operatorname{Stn} 66$

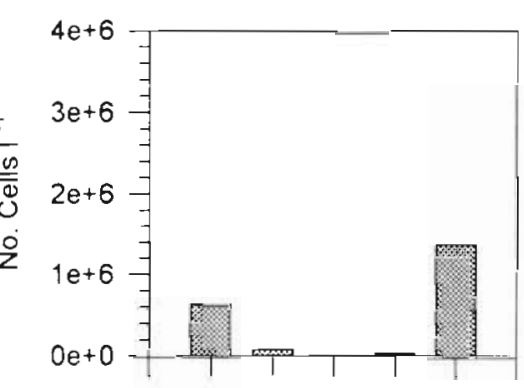

Stn 47

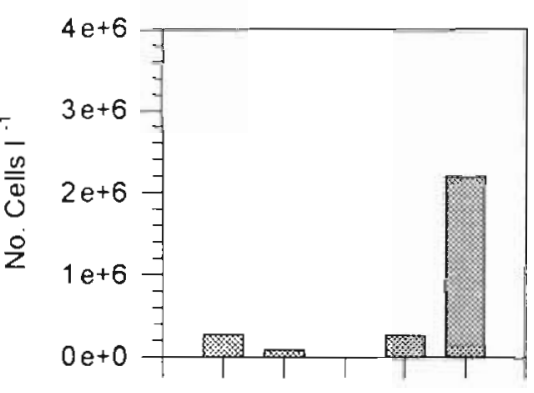

$\operatorname{Stn} 5$

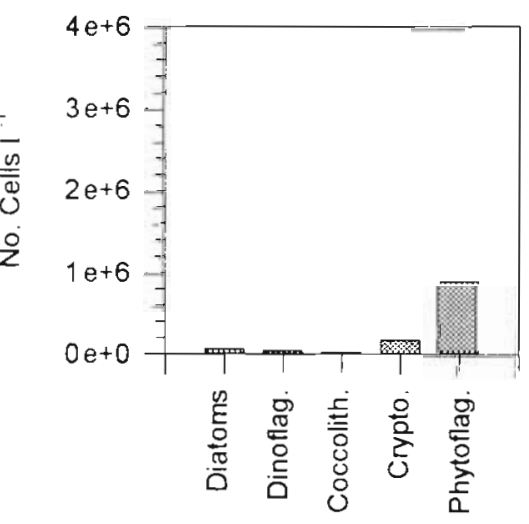

Fig. 8. Cell densities for major taxonomic groups of phytoplankton (diatoms, dino-flagellates, coccolithophores and phytoflagellates) for Stns 66, 62, 47, 13 and 5; July 1991. (Note the linear scale)

(Fig. 3D), we recorded the highest levels of DMS $(16 \mathrm{nM})$ seen on this cruise. The levels of DMSP(P) at Stn $66(62 \mathrm{nM})$ are similar to those at Stn 62, despite much lower surface water chlorophyll a concentrations at $\operatorname{Stn} 66$ than at $\operatorname{Stn} 62\left(3.47\right.$ vs $\left.7.76 \mu \mathrm{g} \mathrm{l}^{-1}\right)$. The high DMS concentrations at Stn 66 may be the result of increased zooplankton grazing there. Although we did not collect zooplankton samples, the densities of copepods are usually higher in this part of the Gulf than in waters further to the east (Townsend et al. 1987).

In July 1991, concentrations of the coccolithophore Emiliania huxleyi were ca 1 order of magnitude lower $\left(10^{5}\right.$ cells $\left.^{-1}\right)$ than seen in previous years in the Gulf of Maine in bloom situations (Matrai \& Keller 1993). These smaller populations were not visible with AVHRR (Advanced Very High Resolution Radiometry) satellite imagery, but were especially abundant in the 
area of Georges and Jordan Basins and on the northwest flank of Georges Bank. At these stations $(n=12)$, the mean DMSP(T) concentration was $66 \mathrm{nM}$ (range = 49.7 to $104.7 \mathrm{nM}$ ) and the mean DMS concentration was $2.7 \mathrm{nM}$ (range $=$ not detectable to $6.0 \mathrm{nM}$ ). Within a bloom population of $E$. huxleyi the previous year (1990), levels of $\mathrm{DMSP}(\mathrm{T})$ reached $368 \mathrm{nM}$ (range = 1.25 to $368 \mathrm{nM}$, all depths) and DMS maxima of up to $8.3 \mathrm{nM}$ (range $=0.82$ to $8.3 \mathrm{nM}$, all depths) were observed (Matrai \& Keller 1993). In spite of the orderof-magnitude difference in population size between the years, levels of DMSP were nearly tripled during the bloom and DMS levels were similar. This suggests one of two things: production of DMSP per coccolithophore cell was enhanced in the non-bloom year, or, other components of the phytoplankton population contributed most of the DMSP. The lack of variation in DMS levels suggests to us that phytoplankton species composition is not the controiling factor in DMS distribution, an observation that is consistent with previous findings (e.g. Turner et al. 1988, Kiene \& Bates 1990, Leck et al. 1990).

In general, concentrations of DMSP in the water column increased from lowest levels in March to highest levels in July, reflecting increases in biomass and a succession from diatom-dominated populations in the spring, with subsequent low DMSP production, to dinoflagellates and prymnesiophytes in summer, and enhanced DMSP production. Although phytoplankton biomass tends to be lower in summer on a Gulf-wide basis, levels of DMSP increase with changes in taxonomic composition. This is demonstrated in Fig. 9 as increasing mean and modal chlorophyll-specific DMSP(P) from March to April to July.

There is some evidence that an inverse relationship exists in phytoplankton between DMSP and nitrogen availability (Andreae 1986, Grone \& Kirst 1992, Keller $\&$ Bellows in press). This is based on the notion that phytoplankton will preferentially synthesize a nitrogen analog of DMSP, glycine betaine, when nitrogen is available. Thus, when nitrogen is limiting to phytoplankton, i.e. during the summer months in temperate waters, DMSP will be higher intracellularly than when nitrogen is abundant. A comparison of DMSP versus $\mathrm{NO}_{3}$ for the July cruise reveals no correlation (Fig. 10). In addition, we explored the idea that a single nutrient, or nutrient ratios, might be used as an indicator of a particular type of phytoplankton population, and thus be related to DMSP production. Since silicate is used only by diatoms, the $\mathrm{NO}_{3}: \mathrm{SiO}_{2}$ ratio might be used to indicate diatoms. Similarly, low $\mathrm{NO}_{3}: \mathrm{PO}_{4}$ ratios have been associated with phytoflagellate populations and harmful algal bloom species (Smayda 1990, 1992). As can be seen in Fig. 10, there is no correlation between DMS or DMSP and nitrate or silicate, nor with the
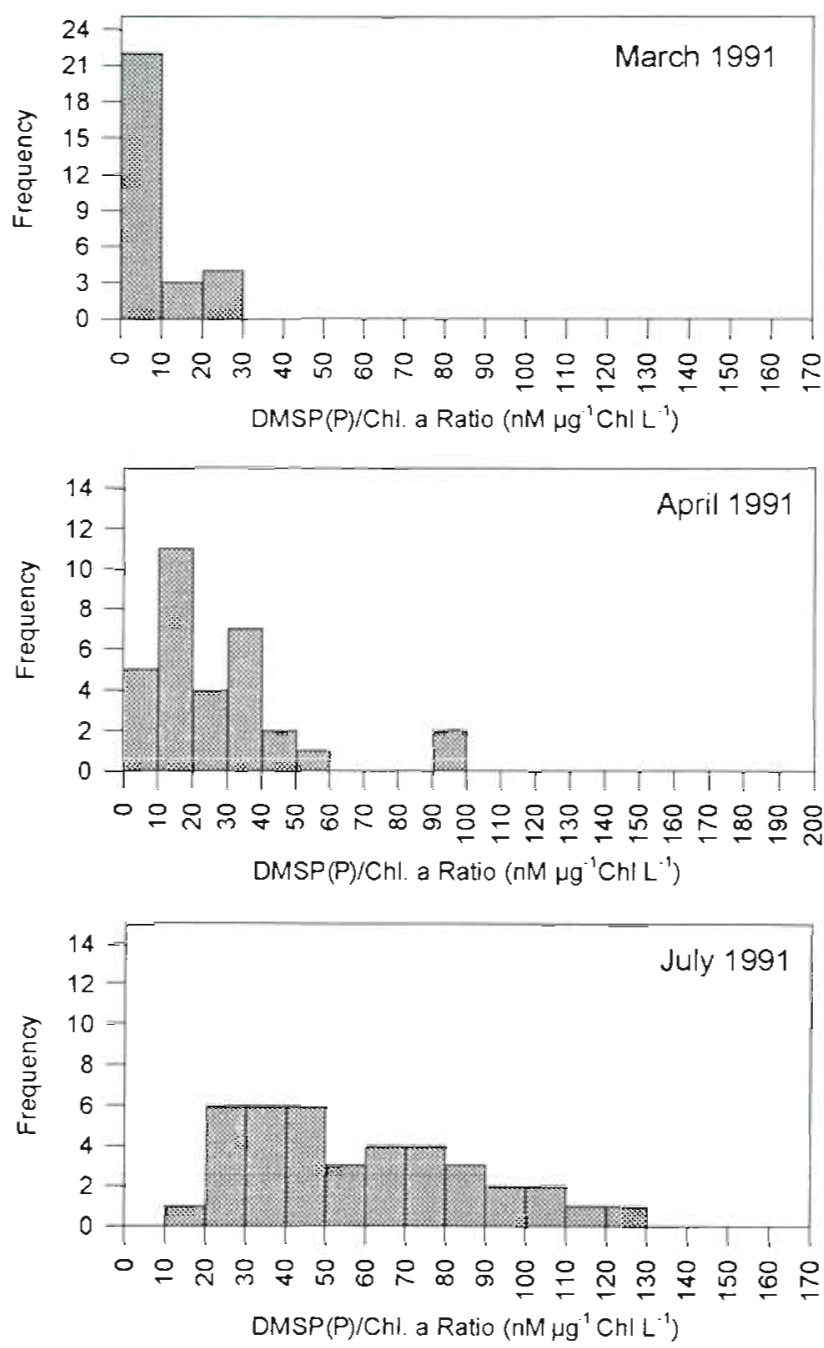

Fig. 9. Frequency distributions of chlorophyll-specific intracellular DMSP [= DMSP(p)], given as nM DMSP(P) $\mu \mathrm{g} c h]{ }_{a}{ }^{1}$

$\mathrm{I}^{-1}$, in surface waters in March, April and July 1991

ratios $\mathrm{NO}_{3}: \mathrm{PO}_{4}$ or $\mathrm{NO}_{3}: \mathrm{SiO}_{2}$. [We used only our summer (July) data for this analysis to meet the need for mutrient-limiting conditions.] Thus, although a relationship may exist between DMSP and nitrogen intracellularly, it does not appear to be possible to relate external nutrient levels with DMSP in any meaningful way.

\section{CONCLUSIONS}

The results from our 3 survey cruises in the Gulf of Maine are in general agreement with those from earlier studies conducted in other temperate regions of the world ocean. DMS and DMSP are higher in summer than in spring, and there are only weak correlations between phytoplankton biomass (chlorophyll a) and 
DMSP, and no correlation between DMS and phytoplankton biomass. It is difficult to ascribe DMSP or DMS to any one group of phytoplankton because it is unusual for any one species to dominate a population, and there are few ways to appropriately weigh the various co-dominants in terms of DMSP production. For example, in the March samples, Phaeocystis, which produces large quantities of DMSP, typically co-dominates with diatoms, which produce far less. Attempts to separate out the various components have been successfully accomplished by Turner et al. (1988) by converting cell numbers to carbon biomass, and then selectively dividing the data into subsets where one group of phytoplankton or another is a major percentage of carbon biomass. Chlorophyll and DMSP data from these subsets were then plotted against each other for each weighted group. We attempted to manipulate our data similarly, using cell numbers of dominant species, but the correlations were not significant. At individual stations, where a single dominant species was present, the relationship was evident but not statistically significant. At such stations the concentrations of DMSP are consistent with the taxonomic composition of the phytoplankton, with areas rich in diatoms found to be relatively low in DMSP, and high cell densities of dinoflagellates and phytoflagellates (mainly prymnesiophytes) associated with higher levels of DMSP. There did not appear to be any clear relationship between nutrient concentrations or nutrient ratios and either DMS or DMSP. Despite the general nature of these trends, they cannot be universally assumed in deriving annual flux estimates or in other modeling activities. For instance, it is typically assumed that certain seasons will be associated with different magnitudes of DMS emissions (e.g. Turner et al. 1988, Bates et al. 1992). Late winter/early spring conditions in temperate waters are typically thought of as periods of low production, both in terms of biomass and DMSP, but as we show here, this is not always the case, as witnessed by the late winter appearance of
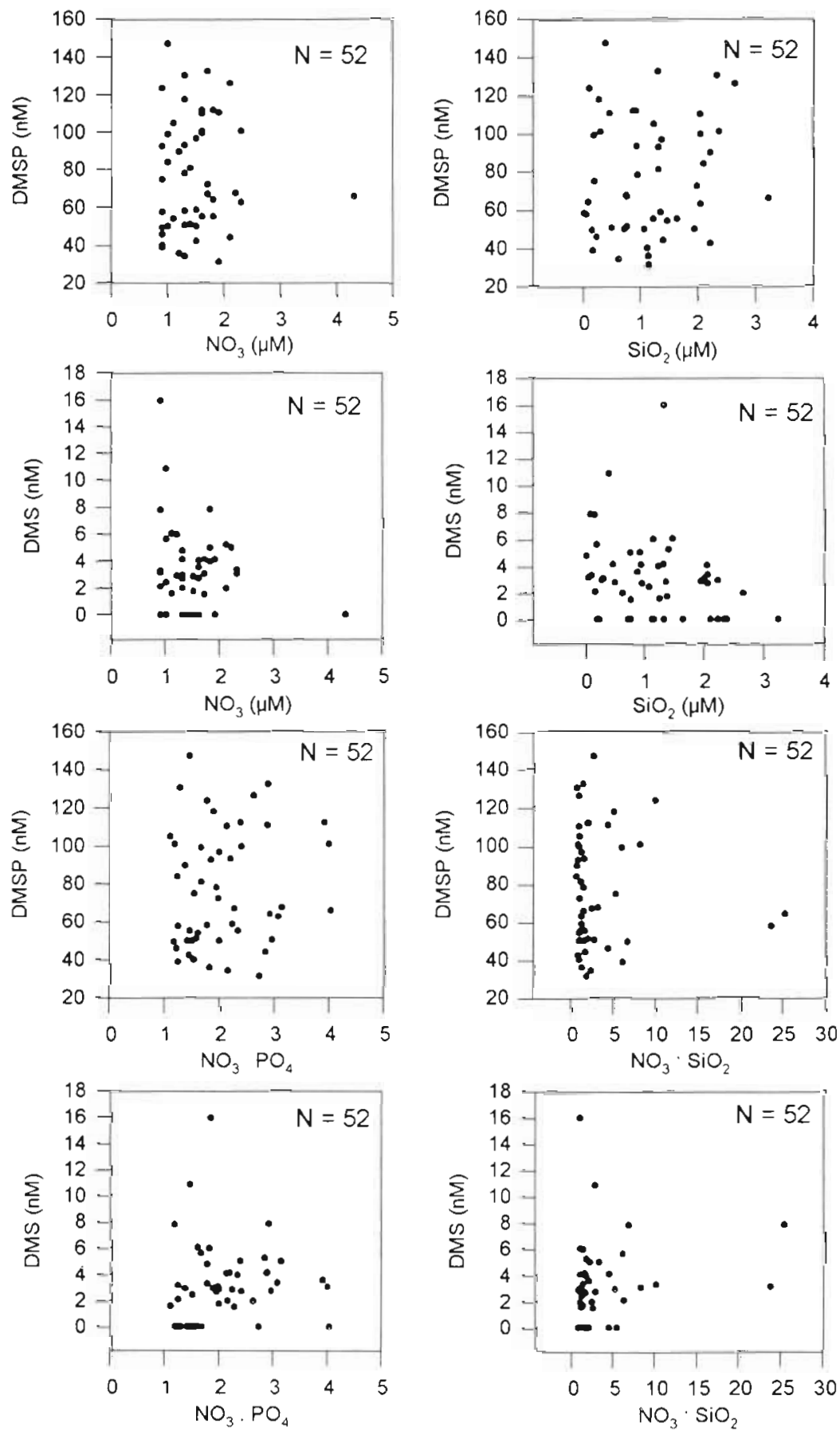

Fig. 10. Top 4 panels: plots of total DMSP (nM) [= DMSP(P) plus DMSP(D)] and DMS (nM) against nitrate and silicate. Bottom 4 panels: total DMSP (nM) and DMS (nM) against nitrate-to-phosphate and nitrate-to-silicate nutrient ratios. All are for surface water samples collected in July 1991 (see Fig. 3)

Phaeocystis and associated high DMSP. In April, a period dominated by the spring diatom bloom, the typical flora can be overridden by an unusual bloom, resulting in dramatically different populations and DMSP levels. This is demonstrated by the appearance 
of the dinoflagellate Katodinium sp., recorded here for the first time as a spring dominant in off-shore waters of the Gulf of Maine. Likewise, summer populations, while a significant source of sulfur, are not always large producers of DMSP, unless there is a bloom of a specific organism like Emiliania huxleyi, as seen in the Gulf of Maine in previous years (Matrai \& Keller 1993).

The occurrence of high DMS concentrations in surface waters during the winter and early spring has potential significance to air-sea flux calculations. Water temperatures at this time of the year are ca $4^{\circ} \mathrm{C}$, and thus microbial activity and heterotrophic grazing may be at minimal levels (Townsend et al. 1994). Bacterial consumption appears to be the major sink for DMS in surface seawater (Kiene \& Bates 1990), although there are no published rates for winter or in polar regions. Kiene \& Service (1991) found very low rates of DMSP metabolism and DMS consumption at $4^{\circ} \mathrm{C}$ in Georgia (USA) coastal waters. Wie suggest that the high concentrations of DMS that we observed during the April cruise may reflect a lack of bacterial activity. As a result, a greater proportion of the DMS may be emitted at the sea surface. Air-sea flux of DMS is a function of the concentration in surface waters, wind speed, molecular diffusivity and viscosity, with the last 2 parameters being a function of temperature. Both solubility and viscosity increase with decreasing temperature, thus making diffusion of a gas less likely (Liss \& Merlivat 1986). The net effect of either property is roughly equivalent, and gas transfer appears to be largely dependent on wind speed and surface concentrations. In rough sea surface conditions transfer velocities increase dramatically, especially when wind speeds are greater than $12 \mathrm{~m} \mathrm{~s}^{-1}$ (Watson et al. 1991). Wind speeds during the spring bloom period are typically higher than in summer, but it is unclear how this combination of factors might affect DMS flux. If microbial activity is minimal at these low water temperatures, concentrations of DMS will be higher and more persistent in the water column, and gas transfer rates may also be enhanced due to higher sustained wind speeds. Future work on winter and early spring (i.e. cold temperature) blooms of DMSP-producing algae should include measurements of bacterial activity and concurrent atmospheric and surface water DMS levels.

Acknowledgements. We thank the captains and crews of the RV 'ARGO-Maine' and RV 'Cape Hatteras' for their able assistance. Special thanks go to Wendy Korjeff-Bellows and Jeff Brown for their assistance at sea and in the laboratory. We also thank Chris Garside for analyzing the nutrient samples, and Tracy Skinner and Elin Haugen for enumerating the phytoplankton samples. This work was funded by U.S. EPA Grant No. R81-9515-020.

\section{LITERATURE CITED}

Andreae MO (1986) The ocean as a source of atmospheric sulfur compounds. In: Buat-Menard P (ed) The role of arr-sea exchange in geochemical cycling. Reidel, Dordrecht, $p$ $331-362$

Andreae MO (1990) Ocean-atmosphere interactions in the global biogeochemical sulfur cycle. Mar Chem 30:1-29

Andreae MO, Barnard WR, Ammons JM (1983) The biological production of dimethylsulfide in the ocean and its role in the global atmospheric sulfur budget. Ecol Bull 35: $167-177$

Barnard WR, Andreae MO, Iverson RL (1984) Dimethylsulfide and Phaeocystis pouchetii in the southeastern Bering sea. Cont Shelf Res 3:103-113

Barnard WR Andreaw MO, Watkina WE, Bingemer $H$ Georgii HW (1982) The flux of dimethylsulfide from the oceans to the atmosphere. J Geophys Res 87:8787-8793

Bates TS, Cline JD (1985) The role of the ocean in a regiona] sulfur cycle. J Geophys Res 90:9168-9172

Bates TS, Cline JD, Gammon RH, Kelley-Hansne SR (1987) Regional and seasonal variations in the flux of oceanic dimethyisuifide to the atmosphere. $\mathrm{j}$ Geophys Res 92 $2930-2938$

Bates TS, Lamb BK, Guenther A, Dignon J, Stoiber RE (1992) Sulfur emissions to the atmosphere from natural sources. J Atmos Chem 14:315-337

Belviso S, Kim SK, Rassoulzadegan. F, Krajka B, Nguyen BC, Mihalopoulos N, Buat-Menard P (1990) Production of dimethylsulfonium propionate (DMSP) and dimethylsulfide (DMS) by a microbial food web. Limnol Oceanogr 35 : $1810-1821$

Challenger F, Simpson MI (1948) Studies on biological methylation. XII. A precursor of the dimethylsulphide evolved by Polysiphonia fastigiata. Dimethyl-2-carboxyethylsulphonium hydroxide and its salts. J Chem Soc 3:1591-1597

Charleson RJ, Lovelock JE, Andreae MO, SG Warren (1987) Oceanic phytoplankton, atmospheric sulfur, cloud albedo and climate. Nature 326:655-661

Dacey JWH, Wakeham SG (1986) Oceanic dimethylsulfide: production during zooplankton grazing on phytoplankton. Science 233:1313-1316

Grone T, Kirst GO (1992) The effect of nitrogen deficiency, methionine and inhibitors of methionine metabolism on the DMSP content of Tetraselmis subcordiformis (Stein). Mar Biol 112:497-503

Haas P (1935) The liberation of methyl sulfide in seaweed. Biochem J 29:1297-1299

Holligan PM, Turner SM, Liss PS (1987) Measurement of dimethylsulfide in frontal regions. Cont. Shelf. Res. 7. $213-224$

Keller MD, Bellows WK (in press) Physiological aspects of the production of dimethylsulfoniopropionate (DMSP) by marine phytoplankton In: Kiene RP, Visscher P, Keller MD, Kirst GO (eds) Biological and environmental chemistry of DMSP and related sulfonium compounds. Plenum, New York

Keller MD, Bellows WK, Guillard RRL (1989) Dimethysulfide production in marine phytoplankton. In: Saltzman ES, Cooper WJ (eds) Biogenic sulfur in the environment. Amererican Chemical Society, Washington, DC, p 167-182

Kiene RP, Bates TS (1990) Brological removal of dimethyl sulfide from seawater. Nature 345:702-704

Kiene RP, Service SK (1991) Decomposition of dissolved DMSP and DMS in estuarine waters: dependence on temperature and substrate concentrations. Mar Ecol Prog Ser $76: 1-11$ 
Leck C, Larsson U, Bagander LE, Johannsson S, Haidu S (1990) DMS in the Baltic Sea: annual variability in relation to biological activity. J Geophys Res 95:3353-3364

Liss PS, Merlivat L (1986) A.ir-sea gas exchange rates: introduction and synthesis. In: Buat-Menard P (ed) The role of air-sea exchange in geochemical cycling. Reidel, Dordrecht, p 113-128

Malin G, Turner S, liss P, Holligan P, Harbour D (1993) Dimethyl sulfide and dimethylsulfoniopropionate in the Northeast Atlantic during the summer coccolithophore bloom. Deep Sea Res 40:1487-1508

Matrai PA, Keller MD (1993) Dimethylsulfide in a large-scale coccolithophore bloom in the Gulf of Maine. Cont Shelf Res 13:831-843

Nguyen BC, Belviso S, Mihalopoulos N, Gaston J, Nival P (1988) Dimethyl sulfide production during natural phytoplankton blooms. Mar Chem 24:133-141

Parsons TR, Maita Y, Lalli CM (1984) A manual of chemical and biological methods for seawater analysis. Pergamon, New York

Sellner KG, Lacouture RV, Cibik JJ, Brindley A, Brownlee SG (1991) Importance of a winter dinoflagellate-microflagellate bloom in the Patuxent River estuary. Estuar Coast Shelf Sci 32:27-42

Smayda TJ (1990) Novel and nuisance phytoplankton blooms in the sea: evidence for a global epidemic. In: Graneli $\mathrm{E}$, Sundstrom B, Edler L, Anderson DM (eds) Toxic marine phytoplankton. Elsevier, Amsterdam, p 29-40

This article was presented by K. Sherman (Senior Editorial Advisor), Narragansett, Rhode Island, USA
Smayda TJ (1992) Global epidemic of noxious phytoplankton blooms and food chain consequences in large ecosystems, In: Sherman K, Alexander LM, Gold BD (eds) Food chains, yields, models and management of large marne ecosystems. Westview Press, San Francisco, p 275-307

Townsend DW (1991) Influences of oceanographic processes on the biological productivity of the Gulf of Maine. Rev Aquat Sci 5:211-230

Townsend DW, Cammen LM, Holligan PM, Campbell DE, Pettigrew NR (1994) Implications of variability in the timing of spring phytoplankton blooms. Deep Sea Res 41 747-765

Townsend DW, Christensen JP, Stevenson DK, Graham JJ, Chenoweth SB (1987) The importance of a plume of tidally-mixed water to the biological oceanography of the Gulf of Maine. J Mar Res 45:699-728

Townsend DW, Keller SB, Sieracki ME, Ackleson SG (1992) Spring phytoplankton blooms in the absence of vertical water column stability. Nature 360:59-62

Townsend DW, Spinrad RW (1986) Early spring phytoplankton blooms in the Gulf of Maine. Cont Shelf Res 6:515-529

Turner SM, Malin G, Liss PS, Harbour DS, Holligan PM (1988) The seasonal variation of dimethyl sulfide and dimethylsulfonoipropionate concentrations in nearshore waters. Limnol Oceanogr 33:364-375

Watson AJ, Upstill-Goddard RC, Liss PS (1991) Air-sea gas exchange in rough and stormy sea measured by a dualtracer technique. Nature 349:145-147

Manuscript first received: August 12, 1995

Revised version accepted: February 26, 1996 